UDC 159.922:37.013.77

\title{
Trauma, Rememory and Language in Holodomor Survivors' Narratives
}

\section{Травма, спам'ятовування та використання мови у наративах свідків Голодомору}

\author{
Larysa Zasiekina \\ Ph.D., Cognitive and Clinical \\ Psychology, Professor
Lesya Ukrainka East European
National University
13, Voli Avenue, Lutsk, Ukraine, 43025

\author{
Лариса Засккіна \\ доктор психологічних наук, \\ професор
}

Email: zasiyekina.larisa@eenu.edu.ua

https://orcid.org/0000-0001-8456-0774

ResearcherID: X-7055-2018

Scopus authorID: 57215414977

Східноєвропейський національний університет імені Лесі Украӥнки

$\triangle$ пр. Волі, 13, Луцьк, Україна, 43025

\footnotetext{
Original manuscript received January 14, 2020

Revised manuscript accepted March 25, 2020
}

\begin{abstract}
The objective of the research is to examine language use in Holodomor survivors 'narratives as psycholinguistic markers of mental trauma and PTSD. The specific objective is to explore rememory as a cognitive strategy of releasing suppressed traumatic events.

Materials \& Methods. 42 survivors of the Holodomor of 1932-1933 in Ukraine were recruited for producing a traumatic narrative. The inclusion criterion for participants was their personal history of being Holodomor survivors. Holodomor survivor is defined as a person who was exposed to the genocide and unprecedented starvation in 1932-1933. The study took place in 2003-2005, average age of participants is 84.5, SD=4.8, 29 females and 13 males. The study applies LIWC (Linguistic Inventory Word Count) to analyze the traumatic narratives and captures linguistic units and the psychological meaningful categories. The study applies the exploratory design


utilizing the independent variables of categories of time, I and cognitive processes and dependent variable of word count in a traumatic narrative for multiple regression analysis, SPSS. 26.

Results. The main issue that emerges from the findings is that categories of I, time, and cognitive processes taken together contribute to word count. However, only categories of time (positive predictor) and cognitive processes (negative predictor) are independent significant predictors of word count. Therefore, we can assume that a poor reappraisal of traumatic events and overestimation of time in the rememory of traumatic narratives indicate PTSD symptoms in Holodomor survivors.

Conclusions. Rememory as a cognitive strategy has a positive impact on developing collective identity and filling gaps in the Ukrainian history, however, it does not affect the therapeutic effect in treating PTSD.

Key words: PTSD, rememory, traumatic narrative, language use, psycholinguistic markers, Holodomor survivors.

\section{Introduction}

Holodomor as a collective, historic and individual trauma is a major problem in multidisciplinary framework, in particular History, Psychology, Linguistics, Social and Political Sciences. Holodomor or Famine of 1932-1933 is associated with an increased risk of transgenerational transmission of trauma in offspring of this genocide in the Ukrainian population. Evidence consistently suggests that the direct descendants of Holodomor survivors have specific emotions (horror, fear, mistrust, sadness, ethnic-related shame, anger, stress and anxiety), and behavioral patterns, aligned with trauma (overeating, intrinsic selfishness and indifference to others, overemphasis on food) (Bezo \& Maggi, 2015). The trauma-based behavioral patterns relate to a strong fear of possible reoccurrence of hunger in future and expressed in seeking security linked to food (Chemtob et al., 1997: 184). Therefore, there is an urgent need to explore the mental trauma of Holodomor survivors, since it also addresses the safety and psychological wellbeing in offspring of the second and the third generations. Moreover, the enchancing emotions and inner states in the second generation of offspring in Holodomor survivors is aligned with healthy aging and an efficient psychological support for this age group.

A number of cross-sectional studies suggest an association between genocide and mental trauma and moral injury in genocide 
survivors, traumatic memory reorganization and effect of traumatic narrative on efficient treating post-traumatic stress disorder (PTSD) (Adenauer et al., 2011; Broom, Kfir \& Dasberg, 2001; Kira et al., 2008). Recently investigators have examined the effects of rememory on recollecting collective trauma and developing collective identity (Nikro, 2019). However, the linguistic mechanisms that underpin rememory as a cognitive strategy are not fully understood. Despite the importance of traumatic narrative in treating PTSD, there remains a paucity of evidence on language use in traumatic narratives and psycholinguistic markers of PTSD.

The objective of this study is to examine language use in Holodomor survivors "narratives as psycholinguistic markers of mental trauma and PTSD. The specific objective is to explore rememory as a cognitive strategy of releasing suppressed traumatic events.

Traumatic memory is defined as traumatic neurosis and PTSD (an anxiety arising as a delayed and protracted response after experiencing or witnessing a traumatic event involving actual or threatened death or serious injury to self or others) in the Oxford dictionary (Colman, 2003). There are different kinds of mental trauma based on the kind of traumatic event (natural disasters, technological disasters, automobile accident) and on the specific victim population (combat veterans, rape victims, victims of domestic violence, victims of child sexual abuse, crime victims) (Meichenbaum, 1994). Evidence consistently suggests that there is a strong association between traumatic memory and PTSD, notably overgeneralization (Lorenzzoni, Silva, Poletto \& Kristensen, 2008), flashbacks and intrusions (Conway, 2005), centrality of traumatic event (Bernsten, Rubin \& Siegler, 2011), involuntary autobiographical memory (Rassmusen, Ramsgaard \& Berntsen, 2015). Furthermore, PTSD as a mental disorder, aligned with alterations in individual memory, requires a recollection of traumatic memory. American Psychological Association revised the main criteria for PTSD, in particular exposure to a traumatic or stressful event, intrusion symptoms, negative alterations in cognition and mood, alterations in reactivity and arousal, duration (symptoms last more than one month), functional impairment and social exclusion. There also some specifications, notable depersonalization and derealization (APA, 2013). Trauma-focused cognitive therapy has been found to be an evidence-based treatment for PTSD (Chemtob, Novaco, Hamada \& Gross, 1997). 
Considering the specifications for PTSD, narrative-oriented therapies are suggested, in particular Trauma-Focused Cognitive and Behavioral Therapy, Narrative Exposure Therapy, which involve individuals into construction of their lifes, including emotions, cognitions, physiology, behavioural and sensory elements (Adenauer et al., 2011; Chemtob et al., 1997). Despite the importance of a traumatic narrative in PTSD treatment, there remains a paucity of evidence on rememory as a tool for producing a traumatic life event.

Rememory as a narrative device and a representational technique was introduced by Tony Morrison to define the narrative strategy of subversive representation in articulating trauma, which it is impossible to narrate (Purkayastha, 2014). The concept rememory is reinvented to capture the recollection of a traumatic individual memory which is unspeakable because of its severe nature. Rememory is closely relates to Afro-American literature and expresses a traumatic experience of slavery. Unlikely the traumatic narrative, rememory is an opportunity for narrator to release individual suppressive traumatic episodes, and simultaneously to reconstruct the discrete and distorted episodes of traumatic experience in the complete and coherent narrative in historical context. Therefore, rememory is a bridge between psychological disintegration of a traumatized person at the individual level and collective traumatic memory, aligned with this trauma. Nikro (2019: 8) suggests to use term «dismemory» instead of «rememory» to define a «more productive notion of forgetting and/or practice of memory as a convenient, politically expedient mode of historical amnesia - the sly collusion of amnesty and amnesia».

Since rememory is linked to the situations of unspeakable terror, grief, intolerable pain, the current study applies this concept to explore the traumatic experience of Holodomor survivors. As Kulchytskyi (2008) argues, the Holodomor of 1932-1933 was a terror by famine resulted at «the killing of people by creating conditions incompatible with life» (p. 90). In other words, it was a death sentence imposed on the Ukrainian population through an unbearable suffering and starvation. Therefore, rememory of Holodomor survivors at the individual level simultaneously represents the collective memory of this genocide in Ukrainians and revitalized historical amnesia. In other words, individual traumatic narratives of Holodomor survivors could be explored as a collective experience of Holodomor, filling the gaps in the Ukrainian 
Historiography. In the current research, rememory is termed as a complex process of releasing repressed traumatic memory at the individual and collective levels.

The recollection of collective traumatic memory aligned with the Famine of 1932-1933 is of crucial importance, since the factors leading to Holodomor were concealed by the Soviet government and even some governments of Ukraine as an independent state, therefore, still remain speculative. Thus the rememory of this tragedy at the individual and collective levels can integrate the Holodomor into a broader understanding of genocide.

Language as an individual ability to narrate is recognized as a main tool for traumatic narrative, which makes a sense for human experience (White, White, Wijaya \& Epston, 1990). However, creating event-based traumatic narrative is not enough for reconstructing traumatic memory and enhancing individual mental health. It is important to express all thoughts and feelings towards the traumatic events and give them a meaningful experience (Pennebaker, 1993). The findings from this research indicate that the improvement of health is associated with a higher frequency of words expressing negative emotions, insight, causal words, and cognitive processes. Thus these words serve as psycholinguistic markers of enhancing individual wellbeing and transforming rememory in a therapeutic narrative.

The findings of recent research suggest that the words expressing external agent, place and time represent the propositional structure of traumatic memory, however time is a negative predictor of an individual's spontaneous self-expression in traumatic narrative of individuals without PTSD. The traumatic memory of individuals who experienced a traumatic event and successfully coped with it without PTSD, focuses on the external agent instead of the internal agent, and shifts focus from past, avoiding overestimation of time linked with the traumatic stressful event (Zasiekina, Kennison, Zasiekin \& Khvorost, 2019).

\section{Methods and Techniques of the Research}

Considering the language units as psycholinguistic markers of traumatic memory and PTSD in Holodomor survivors, the present research tests the following hypothesis $(\mathrm{H})$ : 
$\mathrm{H}$ There is a linear relationship between pronoun $I$ (as a psycholinguistic marker of depersonalization), time (as a marker of derealization), and cognitive processes (as a marker of reappraisal of traumatic experience) and word count (as a marker of spontaneous selfexpression) in the traumatic narrative.

\section{Participants}

42 survivors of the Holodomor of 1932-1933 in Ukraine were recruited for creating a traumatic narrative. The inclusion criterion for participants was their personal history of being Holodomor survivors. Holodomor survivor is defined as a person who was exposed to the genocide and unprecedented starvation in 1932-1933. The study took place in 2003-2005, average age of participants is $84.5, \mathrm{SD}=4.8$, 29 females and 13 males (see Table 1). The participants represented different oblasts in Ukraine and were recruited with the formal letters to take part in the study. After consent forms were obtained, the participants were asked to talk freely about the events with the major focus on their thoughts and feelings. After that the traumatic narratives were transcribed and analyzed.

\section{Method}

LIWC (Linguistic Inventory Word Count) analyzes the traumatic narratives and captures linguistic units and the psychological meaningful categories. LIWC as a software tool refers to the conceptual framework proposed by Tausczik and Pennabaker (2010) to select word meanings linked to the attentional focus, emotionality, social relationships, thinking styles, and individual differences. The current study applies LIWC to discover linguistic units and psychological meaningful categories aligned with PTSD symptoms, notably depersonalization (pronoun I), derealization (category of time, where past and present are mixed), cognitive processes (as a marker of reappraisal of traumatic experience). Since the traumatic narratives were collected and transcribed in Ukrainian, the study applies Ukrainian version of LIWC (Zasiekin et al., 2018). The study applies the exploratory design utilizing the independent variables of categories of time, I and cognitive processes and dependent variable of word count in a traumatic narrative for multiple regression analysis, SPSS. 26. 


\section{Results}

Table 1. Descriptive information for the participants in the current research $(n=42)$ sample

\begin{tabular}{llr}
\hline & \multicolumn{2}{c}{ Survivors } \\
& Frequency & Percentage \\
\hline Gender & & \\
Female/male & $29 / 13$ & $69.0 / 31.0$ \\
Marital status & & \\
Single & 26 & 61.9 \\
Married & 9 & 21.4 \\
Divorced & 7 & 16.7 \\
Ethnicity & & \\
White & 25 & 100.0 \\
Occupational status & & \\
Full-time worked & & \\
Part-time worked & 3 & 9.6 \\
Student & & \\
Retired & 38 & 90.4 \\
Unemployed & & \\
Age & & Min-Max \\
& Mean (SD) \\
\hline
\end{tabular}

Table 2 illustrates the distribution of the main psychological categories in the traumatic narratives of the Holodomor survivors, the mean indices of distribution of the psychological categories in the autobiographical narrative (normal speech, suggested by Tausczik and Pennabaker) (2010) and traumatic narratives in Holodomor survivors, and Cronbach's alpha $\alpha$ to indicate the internal consistency for the personal pronoun $I$, and categories of time and cognitive processes.

Table 2. Results of the LIWC data analysis of Holodomor survivors' traumatic narratives

\begin{tabular}{llllr}
\hline Categories & $\begin{array}{l}\text { The most frequent words } \\
\text { in traumatic narratives }\end{array}$ & $\begin{array}{l}\text { Autobiographical } \\
\text { narratives }\end{array}$ & $\begin{array}{l}\text { Traumatic } \\
\text { narratives }\end{array}$ & $\begin{array}{r}\text { Internal } \\
\text { consistency } \\
\text { (corrected } \boldsymbol{\alpha})\end{array}$ \\
\hline I & I, me, mine & 7.03 & 2.50 & 0.81 \\
Affective processes & terrified, cried & 6.54 & 0.42 & 0.57 \\
Negative emotions & hurt, ugly, nasty, disgustful & 1.19 & 0.29 & 0.55 \\
Anxiety & worried, fearful, afraid & 0.14 & 0.02 & 0.73 \\
\hline
\end{tabular}


Trauma, Rememory and Language in Holodomor Survivors'...

\begin{tabular}{lllll}
\hline Cognitive processes & remember, know, recollect & 12.21 & 9.10 & 0.92 \\
Time & end, until, season & 4.28 & 2.17 & 0.79 \\
Past focus & ago, did, talked & 3.78 & 1.30 & 0.64 \\
Present focus & today, is, now & 15.28 & 1.74 & 0.66 \\
Future focus & may, will, soon & 1.45 & 0.04 & 0.68 \\
\hline
\end{tabular}

Multiple regression analysis has been used to predict the value of continuous variable (word count) based on other independent continuous variables, namely pronoun I, time, and cognitive processes. The assumptions of linear relationship, homoscedasticity, independence of residuals (Durbin Watson $\mathrm{d}=1.46$ ), multicolleniarity (average Tolerance $=0.98>0.1$, and average $\mathrm{VIF}=1.06$, thus $1<\mathrm{VIF}>10$ ) were met. Finally, the size of the sample is above number required by Central Limit Theorem $(n=42>30)$, therefore the assumptions regarding normal distribution of data is also met.

The results of the regression with a forced enter method show that three variables (I, time, and cognitive processes) explained $26 \%$ of word count, $R^{2}=.26, F(3,38)=5.82, p=.002$. The results also show that categories of time and cognitive processes significantly predict the word count, respectively, $b=.34, t(42)=2.48, p=.020 ; b=-.42$, $t(42)=-3.03, p=.004$. Pronoun $I, b=.14, t(42)=.99, p=.32$ does not significantly predict the word count (see Table 3 ).

Table 3. Summary of multiple regression analysis for variables predicting word count for the participants $(n=42)$

\begin{tabular}{lllllr}
\hline Variables & $\mathbf{B}$ & SEB & $\boldsymbol{\beta}$ & $\mathbf{t}$ & $\mathbf{p}$ \\
\hline I & 204.86 & 205.044 & 0.14 & 0.99 & .324 \\
& $\begin{array}{l}(-210.231 \\
619.948)\end{array}$ & & & & \\
time & 30.649 & 12.578 & 0.34 & 2.44 & .020 \\
& $(5.187$ & & & & \\
cognitive & $56.111)$ & & & & \\
processes & -18.513 & 6.116 & -0.42 & -3.028 & .004 \\
& $(-30.895$ & & & & \\
\hline
\end{tabular}

The main issue that emerges from these findings is that categories of I, time, and cognitive processes taken together contribute to word count. However, only categories of time and cognitive processes are independent significant predictors of word count. 
Since the points in a residual plot are randomly dispersed around the horizontal axis between $0-1.5$, a linear regression model is appropriate for the data in the current research (see Figure 1).

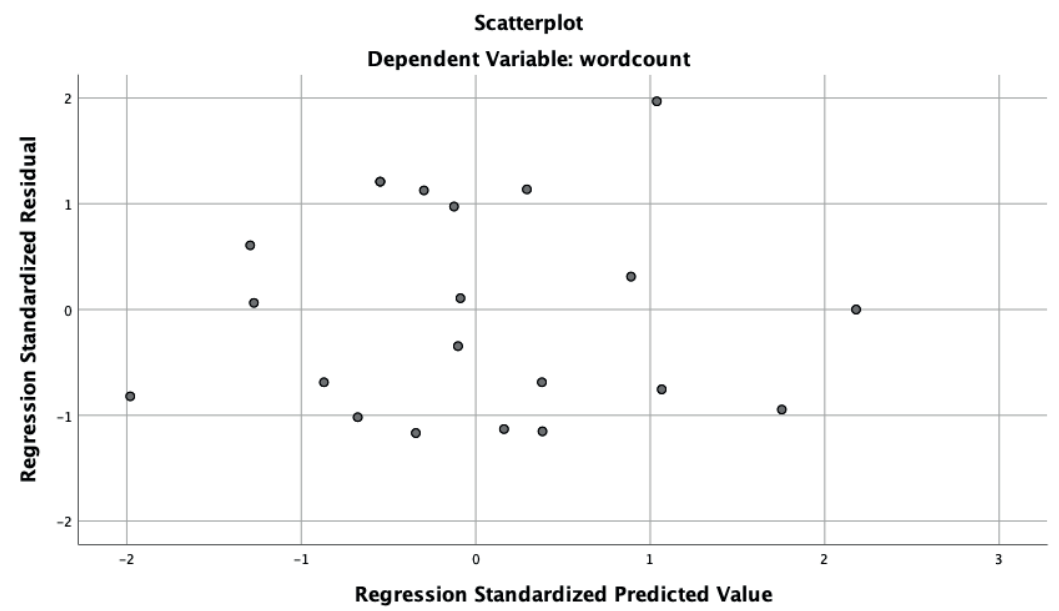

Figure 1. A linear regression model for the data

\section{Discussion}

The study set out to examine language use in Holodomor survivors ' narratives as psycholinguistic markers of mental trauma and PTSD.

With respect to the hypothesis, it was found that categories of time and cognitive processes are independent significant predictors of word count. More specifically, the category of cognitive processes is negative predictor of word count. The possible explanation for this finding is that a low frequency of cognitive processes fits into PTSD symptoms, in particular avoidance and negative alterations in cognition. Therefore, a low frequency of cognitive processes in the traumatic narrative expresses a poor reappraisal of the traumatic events, which is aligned with PTSD. This finding corroborates with other studies indicating that improved health after PTSD treatment is associated with a higher frequency of words insight causal words, and cognitive processes (Pennebaker, 1993).

N.C. Hunt points out:

"Recovery from trauma means making sense of it all again, learning to understand the world as it is in the light of traumatic 
Trauma, Rememory and Language in Holodomor Survivors'...

event, incorporating the new trauma related information into one's narratives» (Hunt, 2010: 126).

Therefore, a low frequency of category cognitive processes is associated with the difficulties to reappraise the traumatic events and accommodate it in the personal understanding of the world by the Holodomor survivors. This finding is in line with the data analysis by LIWC, notably a higher frequency of category cognitive processes in the autobiographical narratives comparatively with the traumatic narratives, respectively 12.91 and 9.10 . The cognitive processes used in the traumatic narratives are mostly aligned with memory recollection, including individual thoughts and emotions towards the tragic events. However, rememory of Holodomor survivors is not accompanied with cognitive processes and expresses a poor reappraisal of the Holodomor, which results at poor psychotherapeutic effect at the individual level, however, contributes a lot to the developing of collective memory, e.g. I remembered as NKVD pursued my father; I know and you know that it was a genocide; I have kept so many deaths in my memory for my entire life; I remember this hunger and will not forget it until the end of my life; I remember a lot of corpses at the Kramatorsk railway station.

As mentioned in the literature review, prior studies mostly have noted the importance of creating an individual traumatic narrative for treating PTSD. However, very little was found in the literature on the rememory as a strategy to release the suppressed memory not only at the individual, but also at the collective levels. In other words, rememory of these events leads to understanding the Holodomor as a collective trauma and developing collective identity in Ukrainians. However, rememory as a cognitive strategy is aligned with cognitive words of memory and mnemonic processes, and does not evolve the cognitive verbs of reappraisal (to be aware, to understand, to make a sense, to capture, to explore, to realize) as a necessary tool for making sense of the event in the entire life and recovering from PTSD. Therefore, rememory in traumatic narratives has a positive impact on developing collective memory and identity in Ukrainians. However, rememory does not affect the positive psychotherapeutic outcome in treating PTSD.

Consistent with the literature, this research found that participants, who witnessed the traumatic event and suffered PTSD, reported using a mixture of present and past time, escaping reality, named as derealization (Zasiekina et al., 2019). One unanticipated finding was 
that there is a higher frequency of category time in traumatic narrative comparatively with autobiographical narrative, respectively 4.28 and 2.17 (see Table 2). However, the study captures the highest discrepancy of category time focused on present in the autobiographical and traumatic narratives, respectively 15.28 and 1.74 . One possible explanation might be that traumatic narrative is aligned with memory recollections of the past events, however, focus on the past could also related to PTSD symptoms, notably intrusions and flashbacks. This conclusion is confirmed by the examples of the traumatic narratives, in particular the pictures of dead people from the past are always present in my mind; they arrested my father in summer 1933, I remember this day in all details; I think that the Holodomor was planned in 1929, after that time the terrified images of hungry people pursued me.

Comparison of the findings with those of other studies confirms that time is a predictor of the length of traumatic narrative (Zasiekina et al., 2019; Pennebaker, 1993). However according to previous findings time is a negative predictor of an individual's spontaneous self-expression in traumatic narrative in individuals without PTSD, since they do not overestimate time like individuals with PTSD (Zasiekina et al., 2019). Therefore, we can assume that focus on time, represented by a mixture of present and past, in the traumatic narratives indicate PTSD symptoms in Holodomor survivors.

\section{Conclusions}

The aim of the present research was to examine the language use in Holodomor survivors 'narratives as psycholinguistic markers of mental trauma and PTSD. This study has shown that that linguistic and psychological meaningful categories, notably personal pronoun I, cognitive processes and time taken together significantly predict the length of traumatic narrative. The most obvious finding to emerge from this study is that time and cognitive processes as independent significant predictors of word count in traumatic narratives indicate a high probability of PTSD in Holodomor survivors, aligned with a low reappraisal of these tragic events and a poor time orientation, resulted from a mixture of past and present, and overestimation of time.

One of the more significant findings to emerge from this study is that rememory as a cognitive strategy has a positive impact on 
Trauma, Rememory and Language in Holodomor Survivors'...

developing collective identity and filling gaps in the Ukrainian history, however, it does not affect the therapeutic outcome in treating PTSD. The findings of this research provide insights for a crucial importance of traumatic narrative incorporating thoughts and emotions towards a traumatic event instead of the focus on time and mnemonic processes in creating traumatic narrative while treating PTSD.

An implication of this is the possibility that Holodomor survivors suffer PTSD after a man-made Famine of 1932-1933. A limitation of this study is that it was not possible to assess PTSD with psychometric measures; therefore, it is only assumed that the Holodomor survivors suffered PTDS. However, this study has raised important questions about the nature of rememory and language use in Holodomor survivors in creating the traumatic narratives. These findings have also significant implications for the understanding of how rememory have an effect on developing collective memory and collective identity of Ukrainians. The results of the current study provide the insights for future research of language use in the traumatic narratives of a genocide survivors.

\section{References}

Adenauer, H., Catani, C., Gola, H., Keil, J., Ruf, M., Schauer, M., \& Neuner, F. (2011). Narrative exposure therapy for PTSD increases top-down processing of aversive stimuli-evidence from a randomized controlled treatment trial. $B M C$ Neuroscience, 12 (1), 127. https://doi.org/10.1186/1471-2202-12-127

American Psychiatric Association. (2013). Diagnostic and statistical manual of mental disorders ( $5^{\text {th }}$ ed.). American Journal of Psychiatry (p. 991). https://doi. org/10.1176/appi.books.9780890425596.744053

Berntsen, D., Rubin, D.C., \& Siegler, I.C. (2011). Two versions of life: Emotionally negative and positive life events have different roles in the organization of life story and identity. Emotion, 11 (15), 1190-1201. https://doi.org/10.1037/a0024940

Bezo, B., \& Maggi, S. (2015). Living in «survival mode»: Intergenerational transmission of trauma from the Holodomor genocide of 1932-1933 in Ukraine. Social Science \& Medicine, 134, 87-94. https://doi:10.1016/j. socscimed.2015.04.009

Brom, D., Kfir, R., \& Dasberg, H. (2001). A controlled double-blind study on children of Holocaust survivors. The Israel Journal of Psychiatry and Related Sciences, 38 (1), 47-57.

Chemtob, C.M., Novaco, R.W., Hamada, R.S., \& Gross, D.M. (1997). Cognitivebehavioral treatment for severe anger in posttraumatic stress disorder. Journal of Consulting and Clinical Psychology, 65 (1), 184-189. https://doi. org/10.1037//0022-006x.65.1.184

Conway, M.A. (2005). Memory and the self. Journal of Memory and Language, 53, 594-628. https://doi: 10.13140/rg.2.1.1434.8647 
Травма, спам'ятовування та використання мови у наративах...

Colman, A.M. (2003). A Dictionary of Psychology. New York: Oxford University Press.

Hunt, N.C. (2010). Memory, war and trauma. Cambridge University Press. https://doi. org/10.1017/CBO9780511845017

Kira, I.A., Lewandowski, L., Templin, T., Ramaswamy, V., Ozkan, B., \& Mohanesh, J. (2008). Measuring cumulative trauma dose, types, and profiles using a development-based taxonomy of traumas. Traumatology, 14 (2), 62-87. https:// doi/10.1177/1534765608319324

Konanur, S., Muller, R.T., Cinamon, J.S., Thornback, K., \& Zorzella, K.P.M. (2015). Effectiveness of Trauma-Focused Cognitive Behavioral Therapy in a communitybased program. Child Abuse and Neglect, 50, 159-170. https://doi.org/10.1016/j. chiabu.2015.07.013

Kulchytskyi, S., Olynyk, M.D., \& Wynnyckyj, A. (2008). The Holodomor and Its Consequences in the Ukrainian Countryside. Harvard Ukrainian Studies, $30(1 / 4), 1-13$.

Lorenzzoni, P.L., Silva, G.L.T., Poletto, M.P., \& Kristensen, Ch.H. (2014). Autobiographical memory for stressful events, traumatic memory and posttraumatic stress disorder: a systematic review. Avances en Psihologia Lationoamericana, 32 (3), 361-376. https://doi.org/10.12804/apl32.03.2014.08

Meichenbaum, D. (1994). A Clinical Handbook for Assessing and Treating Adults with Post-Traumatic Stress Disorder (PTSD). Waterloo: Institute Press.

Nikro, N.S. (2019). Milieus of Rememory: Relationalities of Violence, Trauma, and Voice. Cambridge Scholars Publishing.

Pennebaker, J.W. (1993). Putting stress into words: Health, Linguistic and therapeutic implications. Behavioral Research Therapy, 31, 539-548. https://psycnet.apa.org/ doi/10.1016/0005-7967(93)90105-4

Purkayastha, M. (2014). Rememory as a Strategy of Subversive Representation: A Feminist Reading of Toni Morrison's Beloved. URL: https://www.academia. edu/2542694/REMEMORY AS A STRATEGY OF SUBVERSIVE REPRESENTATION A FEMINIST REĀDING OF MORRIS̄ON S BELOVED

Rassmusen, A.S., Ramsgaārd, S.B., \& Berntsen, D. (2015). Frequency and Functions of Involuntary and Voluntary Autobiographical Memories Across the Day. Psychology of Conciseness: Theory, Research and Practice, 2 (2), 185-205. https://doi.org/10.1037/cns0000042

Tausczik, Y.R., \& Pennebaker, J.W. (2010). The psychological meaning of words: LIWC and computerized text analysis methods. Journal of Language and Social Psychology, 29 (1), 24-54. https://doi:10.1177/0261927x09351676

White, M., White, M.K., Wijaya, M., \& Epston, D. (1990). Narrative Means to Therapeutic Ends. WW Norton \& Company.

Zasiekin, S., Bezuglova, N., Hapon, A., Matiushenko, V., Podolska, O., \& Zubchuk, D. (2018). Psycholinguistic aspects of translating LIWC dictionary. East European Journal of Psycholinguistics, 5 (1), 121-131. https://doi.org/10.5281/ zenodo. 143633

Zasiekina, L., Kennison, Sh., Zasiekin, S., \& Khvorost, K. (2019). Psycholinguistic Markers of Autobiographical and Traumatic Memory. East European Journal of Psycholinguistics, 6 (2), 119-133. https://doi.org/10.5281/zenodo.3637548 
Trauma, Rememory and Language in Holodomor Survivors'...

\section{АНОТАЦІЯ}

Метою дослідження $\epsilon$ вивчення особливостей використання мови та психолінгвістичних маркерів психічної травми та ПТСР у наративах свідків Голодомору. Також дослідження має на меті дослідити спам'ятовування як когнітивну стратегію вивільнення витіснених травматичних спогадів. Матеріали і методи дослідження. 42 свідків Голодомору 1932-1933 в Україні склали вибірку та отримали інструкції якомога невимушено розповісти про трагічні події під час Голодомору. Дослідження тривало упродовж 2003-2005, середній вік досліджуваних 84.5, SD=4.8, 29 жінок and 13 чоловіків. У дослідженні використовувалося програмне забезпечення LIWC (Linguistic Inventory Word Count) для психолінгвістичного аналізу травматичних наративів. Також використано дизайн пояснювального дослідження із множинним регресійним аналізом програмного забезпечення SPSS 26., у якому кількість слів у наративі (маркер спонтанного самовираження у відтворенні травматичних подій) слугувала залежною змінною, а особовий займенник Я (маркер деперсоналізації), категорії часу (маркер дисочіації) та когнітивних процесів (маркер осмислення) незалежними змінними.

Результати засвідчують, що особовий займенник $Я$, категорії часу та когнітивних процесів у сукупності є важливими предикторами кількості слів у наративі. Водночас лише категорії часу (позивний предиктор) та когнітивних процесів (негативний предиктор) $є$ незалежними значущими предикторами кількості слів у травматичному наративі. Таким чином, ми можемо припустити, що зосередження і надання виняткового значення минулому та недостатнє осмислення Голодомору як травматичної події у контексті цілісного життя, може вказувати на симптоми ПТСР у свідків Голодомору.

Важливим висновком дослідження $є$ визначення природи спам'ятовування як когнітивної стратегії вивільнення витіснених спогадів, що має позитивний вплив на формування колективної пам'яті і колективної ідентичності українців, водночас не здійснює позитивний психотерапевтичний вплив у лікуванні ПТСР через недостатнє осмислення цієї події у контексті цілого життя та надання пріоритету минулому над теперішнім.

Ключові слова: ПТСР, припоминание, травматичний наратив, використання мови, психолінгвістичні маркери, свідки Голодомору.

\section{Засекина Лариса. Травма, припоминание и использование языка в нарративах свидетелей Голодомора}

\section{АННОТАЦИЯ}

Целью исследования является изучение особенностей использования языка и психолингвистических маркеров психической травмы и ПТСР в нарративах свидетелей Голодомора. Также исследование исследует припоминание как когнитивную стратегию высвобождения вытесненных травматических воспоминаний. 
Травма, спам'ятовування та використання мови у наративах...

Материалы и методы исследования. 42 свидетеля Голодомора 1932-1933 в Украине составили выборку и получили инструкции непринужденно рассказать о трагических событиях во время Голодомора. Исследование проводилось в течение 2003-2005, средний возраст исследуемых 84.5, SD=4.8, 29 женщин and 13 мужчин. В исследовании использовалось программное обеспечение LIWC (Linguistic Inventory Word Count) для психолингвистических анализа травматических нарративов. Также использовался дизайн обьяснительного исследования с множественным регрессионным анализом программного обеспечения SPSS 26. Количество слов в нарративе (маркер спонтанного самовыражения в воспроизведении травматических событий) служило зависимой переменной, а личное местоимение $Я$ (маркер деперсонализации), категории времени (маркер диссоциации) и когнитивных процессов (маркер осмысления) - независимыми переменными.

Результаты показывают, что личное местоимение $A$, категории времени и когнитивных процессов в совокупности являются важными предикторами количества слов в нарративе. В то же время только категории времени (положительный предиктор) и когнитивных процессов (отрицательный предиктор) являются независимыми значимыми предикторами количества слов в травматическом нарративе. Таким образом, мы можем предположить, что сосредоточение и предоставление исключительного значения прошлому и недостаточное осмысление Голодомора как травматического события в контексте целостной жизни, может указывать на симптомы ПТСР у свидетелей Голодомора.

Важным выводом исследования является определение природы припоминания как когнитивной стратегии высвобождения вытесненных воспоминаний, оказывающее положительное влияние на формирование коллективной памяти и коллективной идентичности украинцев. При этом припоминание не оказывает положительное психотерапевтическое воздействие на лечение ПТСР из-за недостаточного осмысления травматического события в контексте всей жизни и предоставление приоритета прошлого над настоящим.

Ключевые слова: ПТСР, припоминание, травматический нарратив, использование языка, психолингвистические маркеры, свидетели Голодомора. 